\title{
(6) OPEN ACCESS \\ The ghost of pandemics past: revisiting two centuries of influenza in Sweden
}

\author{
Martin Holmberg
}

Correspondence to Dr Martin Holmberg, Culture and Media Studies, Umeå University, Umeå 90187 , Sweden; mhmarhol@gmail.com

Accepted 13 October 2016 Published Online First 8 November 2016

\begin{abstract}
Previous influenza pandemics are usually invoked in pandemic preparedness planning without a thorough analysis of the events surrounding them, what has been called the 'configuration' of epidemics. Historic pandemics are instead used to contrast them to the novelty of the coming imagined plague or as fear of a ghost-like repetition of the past. This view of pandemics is guided by a biomedical framework that is ahistorical and reductionist. The meaning of 'pandemic' influenza is in fact highly ambiguous in its partitioning of pandemic and seasonal influenza. The past 200 years of influenza epidemics in Sweden are examined with a special focus on key social structures-households, schools, transportations and the military. These are shown to have influenced the progression of influenza pandemics. Prevailing beliefs around influenza pandemics have also profoundly influenced intervention strategies. Measuring long-term trends in pandemic severity is problematic because pandemics are non-linear events where the conditions surrounding them constantly change. However, in a linearised view, the Spanish flu can be seen to represent a historical turning point and the H1N1 2009 pandemic not as an outlier, but following a 100-year trend of decreasing severity. Integrating seasonal and pandemic influenza, and adopting an ecosocial stance can deepen our understanding and bring the ghost-like pandemic past to life.
\end{abstract}

\section{INTRODUCTION}

These are the shadows of things that have been. That they are what they are, do not blame me!

\section{-Charles Dickens, 1843, A Christmas Carol in Prose, Being a Ghost-Story of Christmas.}

Most high-income countries are currently engaged in preparedness planning for pandemic influenza and other emerging infectious diseases. However, in their planning scenarios, previous influenza pandemics are usually invoked without a thorough analysis of the events surrounding them-lacking what the historian Charles Rosenberg ${ }^{1}$ called the configuration of epidemics, as distinguished from the epidemic contagion. As Bashford and Strange ${ }^{2}$ have remarked, the way people usually connect with the pandemic past is either to contrast it to the novelty of the coming plague or as fear of a ghost-like repetition of the past.

As the latest in a series of around 10 documented influenza pandemic in Sweden-the 2009 A (H1N1) influenza, or the 'swine flu', led to debates over the appropriate level of preparedness and whether the very anticipation of a catastrophic event might have influenced the way countries responded to the actual outbreak. In its unexpected mildness, the 2009 event has been taken by critics as an example of such anticipatory or prophetic framing that sometimes leads to overreactions. ${ }^{3}$ In some official reports, the 2009 pandemic has been declared an event 'guided by pure luck' and not the expected serious pandemic that is yet to come. ${ }^{4}$

The meaning of 'pandemic' is highly ambiguous and unstable. According to the Oxford Dictionary of Epidemiology, a pandemic is simply "an epidemic occurring worldwide, or over a very wide area, crossing international boundaries and usually affecting a large number of people". 5 The WHO has added the requirement for influenza A pandemics that the virus should be significantly different genetically from circulating human influenza A viruses, that is, many in the population are nonimmune to the new virus. ${ }^{6}$ This addition is meant to exclude seasonal influenzas from the pandemic event, but such a definition is problematic. For example, how large of a proportion of a population needs to be non-immune to make a pandemic? Seasonal influenzas are certainly occurring worldwide and can affect substantial parts of populations, in some cases up to $5-10 \%$, and the burden of disease during the decades after the pandemic introduction is no less than that of the first one or two years of transmission. Furthermore, the actual level of immunity to a circulating subspecies of influenza $\mathrm{A}$ is often not well known, and genetic drift in the virus constantly attenuates immunity. Thus, there is no natural threshold for the transition from pandemic to seasonal influenza. There is also no clear threshold for the start of a pandemic, which often is negotiated and not immediately evident.

Some underlying assumptions among influenza epidemiologists are that influenza pandemics are events with higher mortality than seasonal influenza, with a shifted age distribution in mortality, with a relatively short duration and often arriving in waves, and with varying levels of transmissibility, morbidity and mortality. The outcomes are determined mainly by the properties of the virus and not by the environment or other external factors. Furthermore, variables such as transmissibility and virulence are often seen as independent of each other, and thus they may be freely combined in different scenarios. ${ }^{7}$ Different pandemics are compared over time and space as if their causes and effects are universal and not context dependent. The uncertainty of our knowledge about pandemic impact and spread is often emphasised. No outspoken theory underlies these assumptions, but a reductionist and linear 'biomedical model' can be deduced from them. ${ }^{8}$ 


\section{EPIDEMIOLOGICAL TRANSITIONS}

The epidemiological transition theory ${ }^{9}$ has played an influential role in conceptualising the history of infectious diseases since the early 1970s, and it has been around in a less explicit form long before that. As originally formulated, it considered causespecific mortality in three major stages: (1) the 'age of pestilence and famine', (2) the 'age of receding pandemics' and (3) the 'age of degenerative and man-made diseases'. This model postulates a progression from high to low mortality and fertility driven by economic development and advances in sanitation, public health and medical knowledge. It must be noted that 'the age of receding pandemics' did not play out in the case of influenza (or in the cases of polio and HIV, for that matter). Thus, a new transition, the 'age of emerging infections', has been added to the original scheme of epidemiological transitions to account for the obvious fact that infectious diseases are in no way conquered yet. ${ }^{10}$

Epidemiological transition theory has been criticised for neglecting factors such as poverty, deprivation and social inequalities. ${ }^{11}$ It is evident that all nations and regions do not evolve in the same way, and multiple pathways of transitions must be considered. ${ }^{11}$ The epidemiological transition theory (or rather 'framework') focuses mostly on mortality and neglects issues of disease-specific epidemiology apart from the broad classes of 'infectious diseases' and 'degenerative and man-made diseases'. Its claims of universality and its linearity make it an unsuitable tool for understanding the complex dynamics of pandemic and seasonal influenza.

\section{AIMS}

The aim of this paper is to examine influenza pandemics in Sweden during the past 200 years to see in what ways an analysis of the circumstances and contingencies around the outbreaks contributes to explanations of the epidemiology of the outbreaks. This is a national perspective on a cosmopolitan problem, it focuses on local epidemiology, but it could also be a way to study the limitations of a nationalistic approach in dealing with pandemics. The choice of Sweden can be motivated by the fact that it has the advantage of rich demographic and epidemiological data, which have been collected since 1749 . Data on causes of deaths with varying quality have also been collected since the mid-1700s, and an international classification of deaths was adopted in 1911. Sweden was also one of the countries included in Omran's analysis of epidemiological transitions. ${ }^{9}$ The research questions addressed are to what extent social and cultural contexts can be seen as influencing the progression of outbreaks and whether long-term trends in pandemic severity and impact can be demonstrated. There have been many excellent studies by Swedish historians, economists and demographers on public health and the demographic and epidemiological transitions involved with influenza pandemics, especially those having to do with the Spanish flu. I have tried to refer to some of these in the text, but not in a comprehensive manner due to the brevity of this overview of a rather long history with many fundamental changes in society. I will focus on some social and cultural structures and actions that might have affected the course of influenza outbreaks, whether pandemic or seasonal, but have not been extensively studied previously.

\section{A BRIEF HISTORY OF INFLUENZA PANDEMICS IN SWEDEN The 1831-1833 and the 1847-1848 pandemics}

The population in Sweden was growing rapidly during the first half of the 19th century, from 2.4 million at the start of the century to 4.2 million in 1870 , mainly due to decreasing infant and child mortality while the birth rate remained high. Mortality was characterised by large year-to-year variations due to different infectious diseases such as smallpox, cholera, typhus, dysentery, diphtheria, measles, tuberculosis, bacterial pneumonias, pertussis (whooping cough) and scarlet fever. Cholera epidemics emerged in irregular outbreaks from the 1830 s to the 1870 s, whereas smallpox was gradually decreasing during the entire 19th century due to the compulsory vaccination that was introduced in 1816 .

An influenza epidemic spread over Sweden in April and May 1831. It arrived from Russia and spread westward via the Baltic states, Poland, and East Prussia and arrived in Denmark, Finland and Sweden in April. ${ }^{12}$ In the mortality records of $1831,{ }^{13}$ an excess in deaths of approximately 2000-2500 persons can be seen during the spring months compared with the years before and after. The population in the cities-especially Stockholmwere the most affected. The usual male dominance in mortality was reversed, and more women than men perished during the spring of 1831.

The year after the 1831 outbreak was relatively quiet, but then a new and greater epidemic spread over the world again in 1833 , following much the same paths as in $1831 .^{12}$ This time the influenza was perceived to be more severe, and in Stockholm an estimated quarter of the population (which was then around 100000 people) was affected. ${ }^{14}$ Excess mortality in the rest of the country is not discernible in the records. Opinions are divided on whether the two epidemics were part of the same pandemic or whether there were two different subtypes of the virus circulating, but the former seems more probable. $^{12} 15$ After some quiet years, there was a recurrence of influenza in 1936-1937, in Sweden starting in December of 1936, most likely representing a return of the 1831-1833 pandemic lineage.

In 1847-1848, a new great epidemic (considered by most historians to be a true pandemic) spread over the Mediterranean countries and Western Europe, but it did not affect Sweden in a major way. ${ }^{12}$ However, local country doctors did report influenza cases in $1847-1848^{16}$ as well as smaller outbreaks in 1851 , 1857 and 1863.

At this time, Sweden was still a preindustrial, agrarian society with widespread poverty and large social inequalities. Ninety per cent of the population lived in thousands of sparsely distributed small villages, mostly in the central and southern parts of the country and along the coasts. The median household in the countryside contained 6-10 members living in crowded conditions, ${ }^{17}$ and the household was the centre of both production and consumption. ${ }^{18}$

Domestic and foreign trade increased during this period, and people travelled and transported goods within the country mostly by horse and cart, or by sleigh in the winter, and by boat along the coasts. The new steam engines were used to drive ships, and Sweden had the second largest fleet of steamships in Europe. This fleet connected coastal cities, while inland villages were mostly connected by the marketplaces they frequented. The majority of movements were local, and many villages and regions would periodically have been relatively isolated. Newspapers were not widely distributed and did not contain much information about influenza epidemics. The view of influenza among physicians was that although it was contagious it had a 'telluric' origin, spreading through the air and striking many people simultaneously-a special case of miasmatic theory as opposed to the pure contagionist view, which held that infections were transmitted solely from person to person. The 
'telluric' theory is a reflection of what the outbreaks would have seemed like then: local flare-ups without a known origin and with a high attack rate and local spreading. At the time, influenza was compared and connected with the emerging cholera epidemics and believed to be spread by a similar mechanism. ${ }^{14}$

\section{The Russian flu}

By the time the next influenza pandemic occurred in 1889, Swedish society had changed dramatically. The industrial revolution, which came later in Sweden than on the European continent, was now in full swing. The preceding agrarian revolution had led to a major restructuring of the countryside, and a large number of the former villages had been disbanded and new farms had been built closer to the farmed land. Many farmers lost their land and had to work for wages in agriculture or in the new industries. In spite of a large emigration between 1860 and 1930 to mainly the USA, the population was still growing with a high birth rate and a slowly declining death rate.

A nationwide railroad network had been built, and around it new communities were emerging in place of the old villages. An increased demand for labour led to people moving into the medium-sized and larger cities as well as seeking work in smaller industries along the railroads and the coast. The country thus became much more connected as the population became more mobile.

In early December 1889, a new outbreak of influenza occurred among the artillery corps stationed at Vaxholm outside Stockholm, probably arriving from St. Petersburg where there had been a large outbreak starting in October of that year. The influenza spread quickly to nearby Stockholm and then to other cities and smaller communities, and in only eight weeks it had infected an estimated $60 \%$ of the population, spreading first along the railroad communities and along the coasts. Large cities were affected before smaller communities, and the epidemic reached the more remote rural sites with a delay of weeks up to a month. ${ }^{19}$

Sweden was rapidly industrialising, but was not yet very urbanised, and a large majority still lived in the countryside or in smaller communities, often in poverty. The combination of the railroad as a 'vector' of disease with the majority of the population living under conditions of poverty and displacement made for an explosive configuration. This time the disease burden was reported as heaviest in the rural areas ${ }^{19}$ in contrast to the disease pattern earlier during the 19th century where cities had been the focus of epidemics.

Excess mortality attributed to the Russian flu has been estimated to be around $0.13-0.3 \%$ of those who were infected during $1889-1890^{20}$ In December 1891, the flu returned to Sweden, and this time it was reported to be even more severe. ${ }^{16}$ If both of these outbreaks are taken together, the total influenza-attributed mortality exceeded 7000 persons. ${ }^{13}$ Flu epidemics then returned yearly, following the pattern of seasonal influenzas, although they were still seen as serious events in the newspaper reporting; the term 'seasonal flu' did not appear in the media or in official reports of the time. ${ }^{16}$ The all-cause mortality also took on a more regular pattern during this period. ${ }^{21}$

A thorough report on the epidemic of 1889-1890 in Sweden was compiled by Klas Linroth, ${ }^{19}$ who concluded that the spread of cases in the communities along the railway could best be explained by person-to-person transmission instead of a 'telluric' origin of influenza. Similar views were now being advocated all over Europe, and in light of the new germ theory a bacterial origin to the disease was postulated. In 1892, a bacterium was actually isolated from the airways of diseased influenza patients by Richard Pfeiffer in Germany, which he named Bacillus influenzae or Pfeiffer's bacillus. Few people then doubted that this was the causal agent of influenza.

Public schools had been instituted in 1842, and by the 1880 s almost 800000 children aged 7-14 years attended school (at a somewhat higher proportion of the total population than today, approximately $16 \%$ then vs $12 \%$ now). ${ }^{22}$ This opened up a new epidemic space for influenza transmission, which would have a long-term impact on influenza spread.

Another crucial transition at that time was in the area of communication. The electric telegraph network had been expanded during the 1850 s and the 1860 s to connect the whole country as well as the major capitals in Europe. Telephone networks were introduced in the 1880s in larger cities, and Stockholm at the time had more telephones than any other city in the world. Together with the rapidly increasing daily newspapers and the railroad distribution lines, this led to dissemination of news about the pandemic within 24 hours to large parts of the population. Influenza pandemics became for the first time visible and feared in Sweden. ${ }^{23}$

\section{The Spanish flu}

By the beginning of the 20th century, Sweden had 5.1 million inhabitants. A high birth rate during the last decades of the 19th century led to a high proportion of children and adolescents, and during the 1910 s approximately $40 \%$ of the population was younger than 20 years old. The overall death rate was slowly decreasing and urbanisation was accelerating, with $21.5 \%$ of the population living in cities-28\% if smaller population centres are also included. This was the situation when World War I broke out. Blockades during the war led to food shortages and rationings, with resulting widespread undernutrition.

In June 1918, the first cases of a new influenza-which had already been named 'the Spanish flu' because the first uncensored reports came from Spain and not from the belligerent countries-appeared in southern Sweden, probably brought with travellers from Germany where an epidemic was ongoing. Simultaneously, cases appeared in Gothenburg on the west coast where there were frequent overseas connections with England. Thus, the contagion had probably been introduced from several directions-Norway, Germany, England and Denmark-and had spread throughout Sweden in a few weeks time. It was initially considered 'generally of a mild nature' by the Swedish Medical Board.

The epidemic reached Stockholm in mid-July of 1918 and also began spreading among the army recruits who were stationed in around the 70 garrison cities throughout the country. The press reported cases in large workplaces such as factories, telegraph and telephone stations, and the tram and railway services. There were not many deaths at this stage and there was much else to worry about, so even though people were conscious of the new influenza it was not seen as a major threat at that point. However, reports of increasing numbers of deaths from the continent and also in different parts of Sweden were beginning to appear and led to increasing concerns. ${ }^{24}$

Influenza cases increased in the beginning of September. The role of schools in the spread of the disease was discussed intensively, especially in Stockholm, but there was no consensus around delayed school starts or school closures. In Stockholm, the city council decided against it, but both Gothenburg and Malmö closed their schools during the month of October. ${ }^{24}$ In many places, public gatherings, cinemas and religious meetings were temporarily stopped. Hospital beds, doctors and nurses, although they had increased somewhat during the preceding 
decades, were too few to care for all the severely ill, and there were no effective treatments available.

In 1901, a conscripted army had been instituted, increasing the number of soldiers in the armed forces considerably, and $>30000$ recruits were called into service each year. New barracks were being built in garrisons around the country where the soldiers were to live and train. After the start of the war in 1914, the conscription period was prolonged to 340 days for men between 20 and 42 years of age. ${ }^{25}$ Sweden stayed neutral in the war despite some conservatives' desire to join on the German side.

The mobilised soldiers in their crowded barracks were severely affected by the pandemic of 1918 , and the outbreaks often started in the garrisons before spreading to the surrounding communities. By the end of 1919, approximately $38 \%$ of the soldiers had fallen ill, and 820 of the altogether 117472 conscripted soldiers died during 1918-1919, for a case fatality rate of $1.8 \% .^{24}$ There were widespread demands to send soldiers home and not call in new recruits during the peak of the epidemic, but the government and military leaders denied a general postponement of exercises, which was considered by critics to be a demonstration of military power rather than in the interest of public health.

The number of cases peaked in October and November, but continued into the next year with a new smaller peak in April 1919. Finally, there was an outbreak in the early spring of 1920 that affected more remote areas in the northern parts of the country. There are no precise statistics on the number of clinically ill, and the infection rate varied, but in many places around $50-60 \%$ were affected with the highest incidence in children, the young and the middle aged and the lowest in those $>50$ years old. ${ }^{24}$ The Central Statistics Bureau, which maintained the most comprehensive death statistics, estimated that 34000 people died during 1 year between July 1918 and July 1919 and altogether around 37000 died before the pandemic was considered over. The epidemic was not evenly distributed over the country, and there was almost a threefold difference between counties. ${ }^{26}$ Most of the deaths occurred in the ages of 15-40 years, which led to large numbers of orphaned children and older people without caregivers, as well as to a labour supply shock. ${ }^{26}$ In the years after 1920, influenza returned each season with varying strength, with 1922, 1927, 1931 and 1937 being exceptionally severe seasons. ${ }^{27}$

Two groups had thus been identified during the Spanish flu pandemic as especially important for influenza spread-military troops and school children. In neither case were decisive interventions instituted, and the government was criticised afterwards for its inadequacies in handling the pandemic. ${ }^{24}$ The whole period since the 1890 s can be politically characterised by social and economic inequalities, and increasing class conflicts. Demands for democratic reforms and improvement of living and working conditions-and conservative resistance to these demands-dominated political life. This mirrored how the Spanish flu was perceived by many as an injustice. That influenza was not a socially neutral disease has since been convincingly shown for Oslo (named Kristiania at the time), but would have been equally true for Stockholm. ${ }^{28}$

\section{The Asian and the Hong Kong pandemics}

Economic depression during the late 1920s and the early 1930s had led to high unemployment, housing deficiency and undernutrition in Sweden. The birth rate dropped dramatically, and a population crisis was declared. During the early 1930s, the 'break-even point' of urbanisation was reached (half of the population living in cities). As a consequence, the family and household structure also began to change. Families in the cities were usually small, with a mean of 1-2 children, and the household was no longer the centre of everyday life as it was in the countryside. ${ }^{18}$ In working-class families, the children had to start working at a young age, often after school hours, while children from the middle classes were more protected. The transformation of households and family life to a private sphere, and a new way of constructing childhood into a special way of existence, were social processes that started during the end of the 19th century with the school reform and continued throughout most of the 20th century. During the same period, cities were firmly established as healthier (in terms of mortality) than the countryside, a situation that was influenced by sanitary interventions and other public health measures. ${ }^{29}$

When the economy recovered in the early 1930s, the newly won democratic rights could begin to give results, and several welfare reforms were instituted, including maternity and childcare reforms, social security reform, child benefits, a general pension's reform, etc. A new housing policy was also launched to build new and better homes for the whole population, a process that continued for many decades. In 1938, the Saltsjöbaden agreement was signed between trade unions and employers and became known as 'the Swedish model', and this would have a long-lasting effect as a regulator of labour market conflicts. Political life in this period could be characterised as a consensual and egalitarian building of the welfare state through social engineering, a political project usually called 'Folkhemmet' (the People's home).

During World War II, Sweden claimed neutrality and had to balance between the warring nations, trading with both sides. One million recruits were called into service and were stationed around the nation's borders during the war. According to the cause-of-death register in Sweden, 1941 was an exceptionally severe year for seasonal influenza. ${ }^{27}$

After the war, the intact industry benefited from a large proportion of the population being of working age and a high demand for Swedish goods, and this resulted in an economic boom and a postwar baby boom. The population rose from 7 million to 8 million between 1950 and 1970 . From 1950, compulsory schooling was extended to 9 years, and during the 1970s preschools became generally available, making the school system an extended space for influenza transmission, although general hygienic standards had improved. There was a new wave of urbanisation and active policies to encourage moving to the cities from the countryside. To meet the rising demands from industry, a labour force was also imported from abroad. From having been an emigration nation, Sweden had become an immigration nation.

In the transport sector, the railroad network had been expanded, electrified and nationalised by the 1930s. After the war, the speed of the trains also increased. In parallel with the railroad traffic, private automobile ownership increased and public transport expanded in the bigger cities. Civil aviation had existed since the 1920s but did not carry any significant number of passengers until the 1980s. The transportation flows of people were now increasing rapidly between cities, as well as daily commuting within the larger cities, which increased the possibility of rapid spread of epidemics. In communications, first radio and then from the mid-1950s television had a huge impact on public awareness of political, social and health issues.

The Asian flu first arrived in Sweden in August 1957 with travellers from a youth festival in Moscow and a scout meeting in 
England, and it spread in a few weeks throughout the whole country with cases reported in schools, industrial workplaces and military camps. ${ }^{30}$ The Medical Board issued general advice to the public, but responsibility for mitigation was placed on local authorities. The healthcare system had been greatly expanded after the war, and epidemic wards opened in hospitals in the larger cities.

From October, the number of cases increased rapidly, starting in the southern and northern parts of the country and peaking in early November throughout Sweden. A peak in the number of cases was seen again in April the following year. A large number of soldiers in some regiments fell ill, but the garrisons did not seem to play the same driving role as during the Spanish flu because military medical care and isolation procedures had much improved since the early 1900s. Many schools had to close because of empty classrooms and significant absenteeism was also reported in the postal service, telegraphic service and the national railway company. ${ }^{31}$ Around $15 \%$ of the population, or $>1$ million people, were estimated to have been infected during 1957-1958 based on absenteeism records, ${ }^{30}$ and excess mortality was estimated to be around 2000 persons $^{27}$ for a lethality of around $0.2 \%$.

The fact that influenza was not caused by a bacterium was proven already in $1921,{ }^{32}$ and that it was a viral disease had been shown conclusively in 1933 . When the virus was successfully grown in embryonated eggs, the first vaccines could be manufactured. Influenza vaccine production in Sweden began at the National Bacteriological Institute (SBL) in 1945-1946, a time when memory of the Spanish flu was still alive and seasonal influenza of the H1N1 subtype returned most winters. A vaccine against the new $\mathrm{A}(\mathrm{H} 2 \mathrm{~N} 2)$ Asian strain was ready for trials in October 1957, just when the number of cases began rising. Initially, a trial on military recruits was performed, and then healthcare workers in the epidemic hospitals, home care personnel, and later emergency ward personnel and ambulance drivers were given the vaccine. A few patients in medical risk groups, mainly persons with serious cardiovascular or respiratory diseases, were also vaccinated. However, the supply was limited and the vaccinations were too few and too late to alter the course of the pandemic.

The 1957-1958 flu was the first pandemic to occur in this era of virology and vaccines. The attitude of the time was one of scientism and biomedical optimism, and trust in the new vaccines and in the new antibiotics was high. The virus was seen as a foreign invader that should be conquered with the new medical weapons.

Eleven years later, during the 1968 Hong Kong flu pandemic, the situation had changed somewhat. There was still an atmosphere of economic and scientific optimism, but this was increasingly challenged by new social and political ideologies. New scientific and technological advances had increased the understanding of nature's powers and complexity, and the pandemic was dominantly framed as a natural catastrophe.

During the fall of 1968, there were sporadic cases of the new $\mathrm{A}(\mathrm{H} 3 \mathrm{~N} 2)$ influenza that were imported to Gothenburg by boat from the USA. ${ }^{33}$ However, it was not until December of 1968 and the beginning of 1969 that the epidemic gained speed. A second, more serious outbreak affected the country the next winter season. Altogether 300 000-400 000 people were estimated to have been infected (around 5\% of the population), with a death count of a few hundred. ${ }^{34}$ Even though the Hong Kong flu was both milder and less widespread than the previous Asian flu, the media placed more emphasis on influenza pandemics as natural disasters, and mitigation of the consequences of the outbreak became a higher political priority than more optimistic containment strategies.

The vaccine situation during the Hong Kong pandemic was similar to the situation 11 years earlier. Production of the influenza vaccine at the SBL was not nearly sufficient to meet the need, and large quantities had to be imported from the USA. A total of 700000 doses were distributed, and the medical risk groups recommended for vaccination were extended. As before, selected professional groups, mainly healthcare workers, were also vaccinated. There was a demand for the vaccine by the public, but the experts insisted that it should be reserved for medical risk groups. The newly formed Board of Health and Welfare warned about the vaccine shortage but did not want to issue a priority list for vaccination. Instead, this was left to the county epidemic boards. During the second wave in late 1969, more vaccine was available and the national authorities now issued recommendations for who should receive it. ${ }^{31}$ The new $\mathrm{H} 3 \mathrm{~N} 2$ strain replaced the previously circulating $\mathrm{H} 2 \mathrm{~N} 2$ strain and would continue to cause seasonal influenza for many years to come.

In 1977, an H1N1 subtype appeared in China, which spread via Russia to the rest of the world and became known as the 'Russian flu' or the 'Red flu' in the Cold War spirit. It was very similar to a strain that had circulated during the $1950 \mathrm{~s}$, so people older than 25 years of age were mostly immune. Although it spread worldwide among the young age groups, it was only considered a 'pseudopandemic' because it was very similar to the H1 strain circulating prior to 1957 , which was yet another example of the ambiguous WHO definition. After 1977, it returned regularly together with the H3N2 Hong Kong strain, and the seasonal vaccine now had to be trivalent in order to cover these two influenza A strains as well as influenza B. This two-strain competition in influenza A epidemiology had not been seen before, but it has since become a standing feature of seasonal influenzas.

\section{The $2009 \mathrm{~A}(\mathrm{H} 1 \mathrm{~N} 1)$ pandemic}

From the 1970s, economic crises and more turbulent political periods became the norm. The population reached 9 million in 2004 and is expected to exceed 10 million in 2016, much due to immigration. Swedish society changed with increasing urbanisation, a large influx of refugees and growing socioeconomic inequalities. An agenda of deregulation, privatisation and downsizing of the public sector began dominating the economic policies. This led, among other things, to a decrease in hospital beds per person to among the lowest levels in Europe, which is relevant for the capacity to manage a severe influenza pandemic. After the fall of the Iron Curtain and the end of the Cold War, the armed forces were downsized and fewer soldiers were called into service. The compulsory military service in peacetime was finally abolished in 2009, and as a result the number of soldiers in training decreased by approximately 10 -fold.

Family structures became increasingly fragmented, with a higher divorce rate and more single-person and two-person households, which might have influenced household transmission rates. At the same time, life expectancy steadily increased while the birth rate continued to be low. As a result, the population was ageing, more so than in most other countries.

Car traffic had increased since the 1950s, but during the 21st century this increase has subsided, while automobiles still is the dominant means of transportation. In contrast, air traffic has increased, first domestic flights between 1980 and 1990, and since the 1990 s mostly international flights. However, the most significant transition around the turn of the millennium took 
place in communications, and the digital revolution profoundly increased the spread of information as well as disinformation. With the introduction of blogging and social media, news and rumours started spreading in ways not unlike infectious diseases. This period can be politically characterised by neoliberalism, which placed responsibility for health on the individual, lifestyle promotion, increasing inequalities and emerging insecurities as well as emerging infections, a 'zeitgeist' that highly influenced the framing of pandemics.

The end of the Cold War led to the identification of new military and non-military security issues. ${ }^{35}$ In the area of public health, the authorities placed an increasing emphasis on health security, which was interpreted both as bioterrorist threats and threats from natural epidemic emergencies. Public health policy was increasingly influenced by the European Union (EU), which Sweden had joined in 1995. After the SARS and A(H5N1) bird flu outbreaks during 2003-2005, pandemic preparedness plans were drafted in EU member states and many other countries worldwide. This 'cosmopolitisation' of concerns about pandemic threats, to use a term by Ulrich Beck, ${ }^{36}$ became a new reality in influenza pandemic consciousness.

Thus, a new influenza pandemic had been anticipated for almost a decade, and an advanced purchase agreement for 18 million doses of a pandemic vaccine had been negotiated by the Swedish state in 2007, and a large stockpile of antivirals had been procured. A pandemic preparedness plan was in place and had been audited and tested in exercises, and it was in this context that the 2009 'Swine flu' or A(H1N1) pandemic emerged.

Two minor peaks of influenza occurred during summer and autumn 2009. The main epidemic began in late September when schools had started, and peaked in mid-November when most parts of the country were affected. The outbreak started among school children, followed by younger children, and the number of cases decreased with increasing age. ${ }^{37}$

Immediately after the pandemic was declared by the WHO in June 2009, there was a strong demand for vaccine by the public in Sweden, even though there had been only a few influenza cases during the summer months. Polls showed that between $65 \%$ and $70 \%$ of the population intended to get vaccinated. When the vaccine finally arrived from the manufacturers in the beginning of October, the epidemic had almost peaked. About $60 \%$ of the population still took the vaccine according to recommendations from the authorities, and the uptake was high in all age groups except for young adults. Although the uptake was high, there was considerable confusion caused by the conflicting communications from the authorities, with calls for solidarity at the same time as for individual autonomy. ${ }^{38}$ Whether the mass vaccination changed the course of the pandemic or not has been contested, but it probably had some mitigating effect as judged by later simulations of alternative scenarios.

This context of securitisation and the anticipation of a severe pandemic contrasted with the actual mildness of the Swine flu; only about $10-12 \%$ of the population was affected and just over 30 influenza-attributable deaths were recorded in 2009, and roughly the same number in 2010. More disturbingly, in Sweden the side effects of the mass vaccination $->300$ cases of narcolepsy in children and adolescents-overshadowed the pandemic fatalities. ${ }^{39}$ In the aftermath of the pandemic, some debates over accountability for the actions that were taken and the rationality of mass vaccination and antiviral stockpiling ensued, but these debates were soon replaced by concerns over new outbreaks and pandemic scares, both at home and in other continents.

\section{CONCLUSIONS}

From our Swedish example, we have seen that historical contingencies, political decisions, changing social structures, population movements and biological factors have influenced the distribution and impact of influenza pandemics. There are more epidemiologically relevant processes, such as household economics, transportation, communication, education and governance, than the epidemiological transition framework accommodates. Another insight from this historical review is that the relation between pandemic and seasonal influenza is complex. Before the end of the 19th century, they were not separable at all, but since then the patterns and severity of seasonal outbreaks have changed considerably. In light of this, influenza pandemics could just as reasonably be framed as the continuing circulation of a new influenza lineage (as a 'pandemic era' in Taubenberger's words ${ }^{40}$ ), as opposed to being regarded as catastrophic one-time events. This would emphasise the real burden of influenza on people's lives, and not just the security threat of 'the big pandemic'. For a fuller understanding of influenza epidemiology, theories that include both biological and societal ecologies and the links between them are needed. An ecosocial approach, such as that developed by Krieger, ${ }^{8}$ Singer $^{41}$ or Rayner and Lang, ${ }^{42}$ might better encompass this complexity.

There have been several major social transitions over the past 200 years, and many historical events have had a strong impact on the burden of disease from influenza in Sweden. In the evaluation of the 2009 pandemic, the report of the WHO review committee stated:

Because pandemics occur infrequently, there is a tendency to over-interpret the patterns of the past. For example, it may be tempting when considering the pandemics of 1918-1919, 1957, 1968 and 2009 to conclude that successive pandemics tend to decline in severity. However, four observations are too few to support this conclusion. ${ }^{4}$

In this review, I have included in the analysis additional pandemics and also seasonal outbreaks that show a complex pattern of severity in the Swedish context. This puts the finger on a weakness of the WHO review committee's analysis-it is lacking in historicity and sociocultural context. Severity is an inherently non-linear parameter because the conditions determining it change constantly due to previous pandemic experiences. The heterogeneous impact of the Spanish flu in Europe, also among the Scandinavian countries, is a clear indication that other factors than viral properties are important for influenza transmission and mortality. ${ }^{43}$

A long-term trend of declining severity of influenza pandemics can still be true in some sense for Sweden during the 20th and beginning of the 21 st century. If we try to linearise 'severity', for instance, by using the semi-quantitative two-dimensional scale of Reed et $a l^{44}$ with mortality and transmissibility as parameters, a general trend is seen towards milder and less extensive pandemics, from the Spanish flu to the 2009 H1N1 influenza. Before that the data are more uncertain, but a generally increasing severity from the 1831-1833 pandemic to the Spanish flu seems reasonably well documented. From this linearised view, the Spanish flu represented a turning point and the influenza pandemic of 2009 is not an outlier or an anomaly, but is instead following a century-long trend. Notably, during the same period, there has been a clear trend of increasing national and international interventions to contain the pandemics.

Important social structures such as households and family structure, schools, military training camps and transportation flows have been influential for pandemic spread, and these 
structures have changed profoundly over time, as have public health interventions, medical care technologies and nutrition. The historical position of children in society is particularly important because influenza in many respects is a childhood disease, following the same pattern as 'classical' childhood diseases such as measles and chickenpox, with a high attack rate combined with a relatively low mortality compared with older age groups. However, influenza differs from these diseases in its short-lived immunity, which also makes it an important cause of death in the elderly. This becomes increasingly relevant in societies with ageing populations that are particularly vulnerable.

Explanations and sense-making of pandemics and knowledge of their causes and effects have increased over the years and have become more complex, and several different academic disciplines have contributed to this knowledge, including the humanities. Predictions about the next pandemic are still fraught with uncertainties, and there are too many unknownsvariation in virulence of a new pandemic strain is but one. Nor can we predict the course of future pandemics only by studying the previous ones, although such studies could certainly improve our understanding of the complexities of biological and social ecologies and enhance our analytical capabilities. Instead of seeing past pandemics as reductionists' ghosts, we can make them real and learn real lessons.

Funding Marcus and Amalia Wallenberg Foundation in Sweden (Epdemics, Vaccination and the Power of Narratives) 2012.0097.

Competing interests None declared.

Provenance and peer review Not commissioned; externally peer reviewed.

Open Access This is an Open Access article distributed in accordance with the Creative Commons Attribution Non Commercial (CC BY-NC 4.0) license, which permits others to distribute, remix, adapt, build upon this work non-commercially, and license their derivative works on different terms, provided the original work is properly cited and the use is non-commercial. See: http://creativecommons.org/ licenses/by-nc/4.0/

\section{REFERENCES}

1 Rosenberg CE. Explaining epidemics and other studies in the history of medicine. Cambridge, New York: Cambridge University Press, 1992.

2 Bashford A, Strange C. Thinking historically about public health. Med Humanit 2007:33:87-92.

3 Caduff C. The pandemic perhaps: dramatic events in a public culture of danger. Oakland, California: University of California Press, 2015.

4 WHO. Strengthening Response to Pandemics and Other Public-Health Emergencies: Report of the Review Committee on the Functioning of the International Health Regulations (2005) and on Pandemic Influenza (H1N1) 2009. 2011. http://apps. who.int/iris/bitstream/10665/75235/1/9789241564335_eng.pdf?ua=1 (accessed 8 Apr 2015).

5 Porta MS, ed. A dictionary of epidemiology. 5th edn. Oxford, New York: Oxford University Press, 2008

6 WHO. Influenza virus infections in humans. Feb 2014. 2014. http://www.who.int/ influenza/en/

7 Napoli C, Fabiani M, Rizzo C, et al. Assessment of human influenza pandemic scenarios in Europe. Euro Surveill 2015;20:29-38.

8 Krieger N. Epidemiology and the people's health: theory and context. Oxford: Oxford University Press, 2014.

9 Omran AR. The epidemiologic transition. A theory of the epidemiology of population change. Milbank Mem Fund Q 1971;49:509-38.

10 Barrett R, Kuzawa CW, McDade T, et al. Emerging and re-emerging infectious diseases: the third epidemiologic transition. Annu Rev Anthropol 1998;27:247-71.

11 Zuckerman MK, Harper KN, Barrett R, et al. The evolution of disease: anthropological perspectives on epidemiologic transitions. Glob Health Action 2014;7:23303.

12 Patterson KD. Pandemic and epidemic influenza, 1830-1848. Soc Sci Med 1985;21:571-80

13 SCB (Central bureau of statistics). Causes of deaths. http://www.scb.se/sv_/ Hitta-statistik/Historisk-statistik/Sok-publikationer-efter-amne/
14 Ronander WH. Något om den nu gångbara Influenza (Something about the recent Influenza). Tidskr För Läkare Och Pharm 1833:5:201.

15 Beveridge WIB. The chronicle of influenza epidemics. Hist Philos Life Sci 1991;13:223-34.

16 Medical history database. Årsberättelse från Provinsialläkare. 2006. http://www.ep. liu.se/databases/medhist/ (accessed 10 Feb 2016).

17 Gadd CJ. Det svenska jordbrukets historia. Bd 3, Den agrara revolutionen: 1700-1870. Stockholm: Natur och kultur/LT i samarbete med Nordiska museet och Stift. Lagersberg, 2000.

18 Hedenborg S, Kvarnström L. Det svenska samhället 1720-2014: böndernas och arbetarnas tid (The Swedish society 1720-2014: time of the farmers and the workers). Lund: Studentlitteratur, 2015.

19 Linroth K. Del I: Influensan i epidemiologiskt hänsende (Part 1: Influenza in epidemiological terms). Sweden: Svenska läkaresällskapets Nya Handlingar, 1890.

20 Skog L, Hauska H, Linde A. The Russian influenza in Sweden in 1889-90: an example of Geographic Information System analysis. Euro Surveill 2008;13:19056.

21 Fellman J, Eriksson AW. Regional, temporal, and seasonal variations in births and deaths: the effects of famines. Biodemography Soc Biol 2001;48:86-104.

22 Vinge M. Elever i obligatoriska skolor 1847-1962 (Pupils in compulsory schools in Sweden 1847-1962). Sweden: National Central Bureau of Statistics (SCB), 1974.

23 Ljuslinder K. Överdrivet alarm eller ödesdiger influensa: en studie av nyhetsrapporteringens (re)produktion av betydelser om influensapandemier (Undue alarm or fateful influenza). Kult Perspekt-Sven Etnologisk Tidskr 2015;24:20-30.

24 Åman M. Spanska sjukan: den svenska epidemin 1918-1920 och dess internationella bakgrund. Uppsala, Stockholm, (Universitetet): Distributor, Almqvist \& Wiksell International, 1990

25 Forssberg AM. Lumpen: från mönstring till muck (MIlitary service: from draft to discharge). Stockholm: Atlantis, 2014

26 Karlsson M, Nilsson T, Pichler S. The impact of the 1918 Spanish flu epidemic on economic performance in Sweden. J Health Econ 2014;36:1-19.

27 SCB. Dödsorsaker (SOS) 1911-1996. Hist. Stat. http://www.scb.se

28 Mamelund SE. A socially neutral disease? Individual social class, household wealth and mortality from Spanish influenza in two socially contrasting parishes in Kristiania 1918-19. Soc Sci Med 2006;62:923-40.

29 Lazuka V, Quaranta L, Bengtsson T. Fighting infectious disease: evidence from Sweden 1870-1940: fighting infectious disease: Sweden 1870-1940. Popul Dev Rev 2016:42:27-52.

30 Körlof B, Mörner J, Zetterberg B, et al. Influensaepidemien i Sverige 1957-1958 (The influenza epidemic in Sweden 1957-1958). Nord Med 1958;27:1704-6.

31 Elgh F. Influensapandemiers påverkan på samhället (The impactof influenzapandemics on society). Socialstyrelsen, 2006. http://www.socialstyrelsen.se/ publikationer2007/2007-123-2

32 Olitsky PK, Gates FL. Experimental studies of the nasopharyngeal secretions from influenza patients: I. transmission experiments with nasopharyngeal washings. J Exp Med 1921;33:125-45.

33 Hagman M, Hedström CE. Influensaepidemin i Västsverige 1968-1969 (The influenza epidemic in Western Sweden 1968-1969). Läkartidningen 1971:68:2005-16.

34 Espmark $\AA$, Grandien M, Henricsson L, et al. Dödsfall associerade med Hongkong-influensa (Deaths associated with the Hongkong-influenza). Läkartidningen 1970;67:959-64.

35 Buzan B. Security: a new framework for analysis. Boulder, Colo: Lynne Rienner Pub, 1998.

36 Beck U. The metamorphosis of the world. Cambridge, Malden, MA: Polity, 2016.

37 Swedish WHO National Influenza Centre. The Influenza A(H1N1)2009 Pandemic in Sweden, 2009-2010. Solna, 2011. http://www.folkhalsomyndigheten.se/pagefiles/ 15030/influenza-in-sweden-2009-2010.pdf

38 Lundgren B. 'Rhyme or reason?' Saying no to mass vaccination: subjective re-interpretation in the context of the $A(\mathrm{H} 1 \mathrm{~N} 1)$ influenza pandemic in Sweden 2009-2010: Table 1. Med Humanit 2015;41:107-12.

39 Lundgren B. Narrating narcolepsy-centering a side effect. Med Anthropol 2015;34:150-65.

40 Taubenberger JK, Morens DM. Influenza: the once and future pandemic. Public Health Rep Wash DC 1974 2010;125(Suppl 3):16-26.

41 Singer M. The anthropology of infectious disease. Walnut Creek, California: Left Coast Press, Inc, 2015

42 Rayner G, Lang T. Ecological public health: reshaping the conditions for good health. London, New York: Routledge, 2012.

43 Ansart S, Pelat C, Boelle PY, et al. Mortality burden of the 1918-1919 influenza pandemic in Europe. Influenza Other Respir Viruses 2009:3:99-106.

44 Reed C, Biggerstaff M, Finelli L, et al. Novel framework for assessing epidemiologic effects of influenza epidemics and pandemics. Emerging Infect Dis 2013; 19:85-91. 